\title{
A Survey of the Role of Audit Committees in Promoting Corporate Governance and Accountability in Constituency Development Fund Management: A Case Study of Nairobi Province, Kenya
}

\author{
Samuel Kilika ${ }^{\mathrm{a}}$, Nicholas Mutua ${ }^{\mathrm{b}}$ \\ ${ }^{a}$ Taita Taveta University College, 635, VO İ-80300, Kenya \\ ${ }^{b}$ Taita Taveta University College, 635, VO İ-80300, Kenya
}

\begin{abstract}
The purpose of this study is to present a case for the need for audit committee in Constituency Development Fund to promote corporate governance and accountability in constituency development fund management in Nairobi Province, Kenya. The study provides an analysis and critique of the extent of engagement research in the field of corporate governance and accountability in constituency Development Fund management and present case for further research that may be directed to outside Nairobi province. The study found that the extent of literature in the field of corporate governance and accountability and reporting in contrast to the field to management CDF in Nairobi had largely ignored the practice within CDF organizations. The study argues that CDF can benefit from the methodological and theoretical insights of audit committee and other disciplines. The study suggests where further contributions might be made by future research endeavors engaging with audit committees with organizations. Engaging audit committee in CDF governance and accountability has the potential to improve theorizing practice and the sustainability performance with organizations. Drawing on the methods and theories of other disciplines and the papers in the special issues (of audit committee) the study presents away forward for researchers engaging with audit committees in organizational practicing corporate governance and accountability.
\end{abstract}

Keywords: Corporate Governance Accountability; Audit Committee; Constituency Development Fund

\section{(C) 2013 Published by SSBFNET}

\section{Introduction}

Corporate governance has become a topical issue in the modern world following many corporate failures. The fall of Kenya Co-operative Creameries (KCC), Kenya National Assurance Company (KNAC) in the 1990s and early 2000 and the fall of giant corporations such as WorldCom and Enron in USA, and Parmalat in Italy have brought to the centre stage the issue of corporate governance and intensified the need for improved governance of business enterprises (Strategic Paper for the Ministry of Local Government 2004). The private sector corporate Governance Trust (1999) defines corporate governance as the way authority within a corporate establishment is practised with a view of maximising the utility of the corporate properties as a way of holding shareholders interest and a justification for the stated core values of the organization.Governance in this aspect is about promoting fair, efficient and transparent administration of corporations to meet well defined objectives. İt is also about promoting systems and structures of operating and controlling corporations with a view to achieving long-term strategic goals that satisfy the owners, suppliers, customers and financiers while complying with legal and regulatory factor and audit committee in corporations are key to effective corporate governance. Bramwel (2009), the guidelines require that the internal audit function should be performed with impartiality. Proficiency and due care. The audit committee should determine the areas of control or influence of the internal audit function and in particular. Sigowo (2009).

\footnotetext{
${ }^{a}$ Corresponding author. Tel.: +020 086808.
} 
Review any appraisal or assessment of the performance of members of the internal audit function; Approve any appointment or termination of senor staff member of the internal audit function; Ensure that the internal audit function is independent of the activities of the company and is performed with impartiality, proficiency and due professional care; Determine effectiveness of the internal audit function, and be informed of resignations of internal audit staff members and provide the resigning staff an opportunity to submit reason (s) for resigning. The constituencies Development Fund Act (2003) and Proposed Constitution 2010 survey establishes the role of audit committees in promoting corporate governance and accountability in constituency development fund management, a case study of Nairobi prov ince, Kenya. There has been public outcry on mismanagement and embezzlement of CDF funds by various constituency Development Funds (CDF) board. According to the report by the lobby group, National Taxpayer Association NTA (2010) taxpayers have lost about shs 445 million in the financial year 2006/2007 and 2007/2008. The stakeholders mainly continue to view CDF as alternative institutions and main channels with the ability to provide public services while at the same time exercising some control over governance. However, there are some important areas for improvement among CDF institutions. First and foremost is internal governance, this includes decision making processes, division of roles between the CDF board and audit committee (executives) as well as issued related to the establishments of a clear vision, mission and objectives of the CDF board and CDF audit committee.

A number of surveys and empirical tests have been carried out on the functioning and role of audit teams in various courtiers. According to Maingant and Zeghal (2000and Josh (2004),there has been enough studies on what the key duties and working of different courntiers that satisfied the course of study.The two investigated the motives, composition, selection, and frequency of audit committee meetings, audit committees relationships with internal and external auditors and its broader role. İn the USA, a study by Abbot et al (2002) addressed the impact of certain audit committees characteristics identified by the blue ribbon committee on the improving the effectiveness of corporate audit committees on the likelihood of financial misstatement (Braitta 1999). İn Kenya, several studies have been carried out in the area of corporate governance, Jebet (2001) examined governance practices of quoted companies, Mwangi (20002) examined the governance practices in the insurance industries while Mucuri (2002) examined the governance in motor vehicle industries, Gakuo (2003) and Wangombe (2003) examined governance practices among the NGO's in Nairobi and in cooperative societies respectively. Mwangi (2004 looked at factors influencing board composition. A study by Hussein (2003) examined the audit chapter, composition frequency of meetings and effectiveness of audit committees. The study, however, only examined whether the audit committees complied with CMA guidelines. According findings by both Goddard (2000) and Kalbers, Fogarty (1993) showed that audit committees emerged asparamount in the yester years although there was a slight divergency in some other earlier studies as per the values. According to findings of the research by Pomeranz (1997),it indicated that the value of whether audit committees are actively discharging their important responsibility remains insufficiently under stood.

More recently Riro (2005) conducted a survey of the audit committees and corporate governance in Kenya with the objective of determining the role audit committee can play in good corporate governance. Mutiga (2006) conducted a case study on the perceived role in general auditor in corporate governance in general public institutions. İn this study he focused on the role of an auditor and sought to determine the role of external auditor in injecting good corporate governance in Kenyan organizations. There was need, therefore, or a study to be carried out to examine the role of an audit committee can play in promoting corporate governance and accountability management of constituency Development funds in Nairobi province in Kenya. The main objective of the study is to establish the role of the audit committee in promoting corporate governance and accountability of constituency development fund management in Nairobi province. İ this study the major question relies on the roles of audit committee in promoting corporate governance and accountability of constituency development fund management in Nairobi Province. This study attempts to provide a valid body of knowledge for Government, potential investors, policy makers, academia, regulators, the IMF, World Bank and the Capital Market Authority

\section{Literature Review}

\subsection{Theories of Corporate Governance}

Corporate governance explains how to promote fair, efficient and transparent administration of corporations to meet well defined objectives. İt is also about promoting systems and structures of operating and controlling corporations with a view of achieving long term strategic goals that satisfy the owner's suppliers, customers and financiers while complying with legal and statutory requirements. Further it involves meeting environmental and society needs and an 
efficient process of value-creating and value adding. (CMA guidelines on corporate governance issue 2002). Establishment of an audit committee and internal audit function represent an important step towards promoting good corporate governance. A board that works together with its internal audit will have access to fresh and independent perspective on some of the issues that really matter to the business. The guidelines of corporate governance developed by the CMA require that the board of directors regularly review the company processes and procedures. This will ensure the effectiveness of the company's internal systems of control and that the accuracy of its reporting and financial results are maintained at a high level all times. The internal audit department perfectly performs this role for the board of directors as it discharges its responsibilities by reviewing and evaluating the effectiveness of internal control systems and providing assurance to the management that the systems of internal control are adequate, effective and reliable (effective corporate governance framework CMA 2002).

\subsection{Main players in Corporate Governance}

The main players in corporate governance include the management, company secretaries,auditing groups, management team, and other interested parties inthe auditing environment. The Board of Directors has a duty of setting up the company's strategic aims, providing the necessary leadership and supervising the management of the business. İt also reports to the shareholders on their stewardship and outlines functional areas of the Chief Executive Officer (CEO) and senior managers particularly the head of finance and the company secretary. The composition of the board should be balanced in terms of executive and non-executive directors of diverse skills or expertise in order to ensure that no individual can dominate the Board's decision making process. There should be formal and transparent procedures of appointing directors to the board. All directors should disclose any potential area of conflict that may undermine their individual position or service as a director. Executive directors should have a fixed service contract with a provision for renewal subject to performance appraisal.

\subsection{Corporate Governance and Audit Committee Effectiveness}

Following high profile corporate governance failures there have been proposals and actions in a number of countries concerning the responsibilities and powers of audit committees, their mandatory or voluntary status, membership and independence. This trend of development can be seen as part of a wider agenda regarding the potential 'globalization' of corporate governance. Following similar projects in areas of financial reporting, harmonization of governance structures internationally is an important area of current development. İndications of these are apparent from evidence of a significant rise and harmonization in the use of audit committees internationally (Collier and Zaman, 2005), and form the European Commission's $8^{\text {th }}$ Directive requiring all public interest entities in the European union to have an audit committees. The effectiveness of audit committees has been a subject of some concern to both researchers and regulators (see for example Spira, 2002 and Turley and Zaman, 2003 and 2004). A typical example of this concern is the following reaction to the USA case of Enron, where the audit committees has been criticized for failing to identify or prevent certain practices within the company.

\subsection{Historical Development of Audit Committees}

The Sarbanes-Oxtey explained that the constitution that an audit as an organ set out with the objective of carryinng out the exercise of rendering explanations about the financial positions amongst the board of directors of an issuer for the purpose of overseeing the accounting and financial reporting processes of the issuer and audits of the financial statements of the issuer. Pomeranz (1997) stated that the audit committee represents a standing committee of the board of directors that is charged with dealing with audit related concerns. The Accountants international Study Group (1977) cited by Goddard (2000) defined the term committeeas a management team of officials charged with sole reasons of reviewing the final results of meetings as they are forwarded to the top management of directors. Audit committees were first publicly endorsed in 1940 in the aftermath of the McKesson \& Robbins (1939) scandal in the USA, when both the Securities and Exchange Commission (SEC) and the New York Stock Exchange (NYSE) advocated their creation (Attwood 1986). The NYSE issued recommendations, which stated, Where applicable, the selection of the auditor by a special committee of the board appears desirable (Braiotta 1999). Although the term audit committee was not mentioned as such, several companies, for example,due to discoveries of wide spread scandals prompted action to do away with the vicewhich if allowed to thrive could have bred disastrous results that blurred the image of accounting fraternity at large. By 1967 the concept of the audit committee received little support, and the functions of this committees remained undefined (Braiótta 1999). İn July 1967 the executive organof the A İCPA proposed the importance of having boards of management outside the frame work of the publc corporations' management directors. External auditors started communicating with the audit committees whenever any significant 
question having material bearing on the company's financial statements had not been satisfactory resolved at the management level (Braiotta 1999). Braiotta (1999) goes on to state that during the 1970's the work of the auditing teams in U.S received some attention due to discoveries of unethical practices and therefore precipitated into the investing public demanding for greater corporate accountability to increase the confidence in the quality of financial reporting. In view of the separation of ownership and management, stakeholders in the wider spectrum desired that their confidence affirmed in the processing procedures before production of final consumable documents are released to the publc domain. As a way of reacting to the public outcry, SEC in 1972 issued Accounting Series Release number 123 Standing audit committees composed of outside the management' scope, requiring the acknowledgement by the established public corporations to show the degree of composition by both directors and outsiders.

\subsubsection{Functions of audit committees}

Audit committees should have responsibilities tailor made for their organization. According to Beans (1999),the basic role of the committees is to provide smooth working of the directors in their mandate in checking thoroughly data in related to financial records meant for all users both external and internal as well as others. The study showed the over all functioning as well as opeations of the audit committee that are channels of delivering information to auditors in all aspects. The extent to which the reports have to go and get the required feedback. According to Cooper and Lybrand (1995) an elaborate structure that is used in the operations of the committee is well outlined. These findings continue to explain the well established personnel structure that has been in use investigating about the authedicity and correctness of the workings inspite of the fact that alot of deviations that have been discovered by the studies done. Dezoor t (1997),concluded that the duties of the audit committee was stated and conclusively structured in three key areas.

\subsubsection{Committee Charter}

Pomeranz (1997) stated that a charter was the official explanation of the established mandate outlining an audit body was. According to Guy (2001) it emerged that it was a major priority to have the auditing roles carried by any organized body. The board should approve the charter, and it serves as a guide to the auditing team in the excutionof the allocated duties. Brolotta (1999) concluded that the effeciency and effectiveness of auditing outcomes was a subject that the management had to prioritize and set by laws that needed to spearhead the corporate goals through its contents and daily practice. KPMG (1999), supported the purpose of a water tight structure that helped the management get desired results as the charter outlined and applied in achieving the set objectives that are the overriding concern of the document.which is useful and central to the core business of the organization.

\subsubsection{Independence and financial literacy of audit committee members}

Braitta (1999) concluded that the orientation of the members played a pivotal role in the effectiveness of the auditing process. Further the study established that the composition of the members needed to be collected from a wide background that was both from the finance and non financial to give it a balanced taste. The capital markets authority (CMA), (2000),concluded that the unbiasness of the directors was critical since it gave user of final reports that there was a sense of impartiality among the directors who were supposed to be independent in their opinions. Despite the Attwood (1986) also concluded that the organizational culture that a given business entity thrived from dictated what the elements of committee were.According to Pomeranz (1997) and Herdman (2002)concurred that there was a growing concern about the independence or unbiaseness of the independent members through a clear cut process and procedure. Herdman (2002)quoting former SEC chairman Rodhilis, argued that the inability of these committee was a failure in the structured controls that lacked the expected threshhold of an unbiased position in the judgemental roles of auditing members in the nomination exercise.

\subsubsection{Meetings and Agenda}

According to Attwood (1986) findings, he concluded that time tabled committee meetings needed to be done clearly and in good order. The timing was a preliquisite to elementary production of required accounts that called for the participation of all concerned divisions or ares within the structural work.according to Graziano (2004), though there was some variations from Guy (2001)observations but both held that the role of meeting together was a central concept that was ideal to practice. Herdman (2002) stated that a6dit committee members must make the time, and take the time, to achieve an adequate understanding of the company's financial reports, to have time to consult with outside counsel and experts if necessary, to ask the tough and incisive questions, and to obtain answers that make sense. As such Herdman (2002) argued that an effective audit committee requires a commitment of quality and quantity time to 
allow thorough deliberations and discussions. This means that proper up-front planning, conduct of meetings and follow-up is essential. Research studies involving meeting frequencies of audit committees and company variables have created some interest. Menon and Williams (1994) in studies by Joshi (2004) studies about several companies indicated that sitting auditing committees positively influenced the participation of the management officials as the size of the firm and assessment within the company was done. Price Water House Coopers (1999) found that audit committees among European companies met on average three to four times a year. The chairperson of the audit committee should prepare the meeting agenda. The chairperson, working with the chief finance officer, the audit manager, and the general counsel, along with input from external auditor, should prepare detailed agenda with topic and time allocations to help keep the committee focused. The chairperson should circulate proposed audit committee's agenda to all committee members to obtain their inputs about topics that should be added. Under no circumstances should management alone prepare the audit committee's agenda. Meeting agenda and related materials should be distributed to committee members in advance of scheduled meetings (Guy 2001).

\subsubsection{Self-evaluation}

A İCPA (2004) recommended that an audit committee should conduct a comprehensive self- evaluation on an annual basis. The self-evaluation can take different forms, involve a number of participants, and use diverse techniques. Most important, however, the self-evaluation should adopt a straightforward approach that will aid the audit committee in reassessing its strength and weaknesses and lay a foundation for future improvement. İt is important that the audit committee evaluate its performance by asking specific questions about the impact it has had on the organization, most importantly, in its financial reporting process, the annual audit, the relationship with the independent auditor, and members of management. The audit committee should include the chair of the board in the evaluation session and ask for his/her input. The evaluation should be comprehensive and should involve all audit committee members and the committee chair. The chair should consider the result of the audit committee member's evaluation of each other in the text of the chairs evaluation of the members. The chair should consider whether any member should be rotated off the committee, and this should be done in consultation with the chair of the board. The member's attendance records and level of participation should be considered during this process.

\subsubsection{Relationship with management, internal auditor and external auditor}

According to the Blue Ribbon Committee (1999) the interactive behavior among the different parties like the management and its established auditing environment needed to be free biaseness with effective flow of information to enhance confidence and quality performance that upheld the image of the core values of that revolved around sound management and governance.zabihollah (2003) in study's findings outlined that sound auditing techniques called for appropriety application of produce by both the auditing individuals as well as the board of directors in the broad sectors of the functions of the corporations. According to the study byLordial on New York Stock Exchange (NYSE) it is imperative that the CEO only attends meeting only by invitation as the outcome of resolutions of the committee depended on the level of knowledge and its level of application within the scope of practice, Terrell (2003). Haka and chalos (2003) indicated that auditing committee needed to be open and ready to tackle emerging risks as they occurred and arouse the corporate sensitivity in financial presentations of reports that indentified anticipated risks. A study by Haka and Chalos (1990) cited by Reinstein (1996), found evidence of agency conflict between management and the audit committee chair.

\subsubsection{Challenges in Audit Committees Relationship}

The challenge when reporting performance outcomes of shared programs reveals a lack of an effective governance framework that transcends the traditional vertical silos of governance. As a priority, there is a need for frameworks and appropriate reporting mechanisms for shared programs. The British government's Invest to Save Budget encourages cross-departmental co-operation by providing financial incentives to two or more agencies to jointly deliver services which are more efficient, innovative, joined-up and locally responsive (National Audit Office, 2001). The British government has recognized that the existing system of allocating resources and accounting for budgets is a barrier to joined-up government, and as an alternative, it has introduced a model which emphasizes separate funding to lead agencies for priority programs. Budgets are pooled, and funds may be managed by a single agency, though accountability is shared by a group of ministers. The Auditor General of Canada (2000) has also proposed a framework for collaborative arrangements under which the department designated to lead the management of a horizontal program has the critical role of ensuring that issues are managed in a way that meets the partners' objectives and obligations. The lead department needs to have the necessary power to discharge its responsibilities, to ensure that 
partners are kept informed, that performance is monitored, and that partners live up to their commitments. Joint initiatives rely on clear expectations, and each of the partners knowing in concrete terms what is expected of them. This requires an up-front framework agreement, and credible reporting which depends on the collection and sharing of reliable and compatible data.

\subsection{Accountability Theories}

Accountability requires an account of the extent to which the objectives for which the resources were entrusted have been achieved. This accountability is described as a contract between an agent and a principal and arises from a duty upon the agent and the rights of the principal (Gray, et al., 1987). The principal can be entirely passive and this will not matter to the agent whose duty nevertheless is to account - the passive principal is merely waiving his or her rights to the information (Stewart, 1984). On the other hand, it has been argued by Tricker (1983) that the agent only has a duty to account to principals who demand information and are willing to enforce the contract.Much of the research on corporate accountability suggests that regulation is the only way to ensure that companies provide complete and comparable reports. Gray et al. (1987) suggest a compliance with standards approach, and the proliferation of reporting guidelines mainly on environmental issues. Many academics consider that only mandated, standardized reporting will produce the comprehensive information needed to assess corporations' performance. Support for such a regulated approach is provided by evidence that voluntary disclosure levels are much lower than those for mandated disclosure (Guthrie \& Parker, 1990). A more persuasive argument for the use of legislation in making companies more accountable is that social and environmental matters are too complex and crucial to be left entirely in the already overburdened hands of corporations. Thus, by opening up organizations in order to inform stakeholders, it enables the stakeholders, rather than management of organizations, to express their choices about critical issues. One of the problems associated with reporting against mandatory standards however, is the question of who ensures compliance with those standards and what penalties apply for non-compliance. For implementing agencies it can be argued that accountability should be more focused on accounting for their actions and effects on society, rather than accounting for their financial performance (Bebbington \& Gray, 1993).According to Ebrahim (2003), agency accountability is a dynamic concept and arguably more complex than simply making agents transparent and allowing public scrutiny, which highlights the issue of competing stakeholder interests. Organizations must deal with competing requirements of various stakeholders, and most often choose to satisfy the needs of their primary stakeholders first and often at the expense of secondary stakeholders' needs as their principle goal is aligned with the needs of these primary stakeholders. Brown \& Moore (2001) postulate that since agencies are not coherently aligned with one another they must, like other organizations, also prioritize their stakeholders. This can have dire consequences for their existence as their goals to provide welfare may not always be aligned with the goals of their donors.

\subsubsection{Stakeholders Theory of Accountability}

Creating accountability in public service is extraordinarily complex. There is a complex web of policymakers and providers in such responsibility. The issue of accountability is also complicated by the difficulty in defining and measuring financial outcomes. Extensive research suggests that about two-thirds of the variation in achievement is the product deliberate neglect and slim commitment to account (Ladd, 1996). The stakeholder theory has been used quite extensively in the management literature since Freeman's landmark book Strategic Management: A Stakeholder Approach was published in 1984. He proposes that current approaches to understanding the business environment fail to take account of a wide range of groups who can affect or are affected by the corporation, its stakeholders. He further argues that in order to manage effectively in turbulent times which typifies the dynamic nature of the business environment of today, the stakeholder theory offers a way to address the ever changing demands brought about by different groups having legitimate stakes of varying degrees from the organization (Jensen \& Meckling, 1996). The basic proposition of the stakeholder theory is that the organization's success in the attainment of accountability standards is dependent upon the successful management of all the relationships that it has with its stakeholders. When viewed as such, the conventional view that success is dependent solely upon maximizing shareholders' wealth is not sufficient because the school entity is a nexus of explicit and implicit contracts. Furthermore, the stakeholder theory assumes that organizations have the ability to influence not just society in general but its various stakeholders in particular. İ developing the stakeholder theory, Freeman incorporates the stakeholder concept into categories: planning and policy model; and corporate social responsibility model of stakeholder management (Jensen and Meckling, 1996). 
The stakeholder analysis focus on developing and evaluating the approval of the organization's strategic decision by groups whose support is required for continued existence. The stakeholders in this model would include the Government, CDF, Audit Committee target groups and general public. Although these groups are not adversarial in nature, their possibly conflicting behavior is considered a constraint on the strategy developed by management to best match the resources with the environment. İn the second model, the corporate planning and analysis extends to include external influences which may be adversarial to the firm. These adversarial groups may include the regulatory, environmentalist and/or special interest groups concerned with social issues. The second model enables organizations to consider a strategic plan that is adaptable to changes in the social demands of nontraditional stakeholder groups (Chan and Kent, 2003).

\subsubsection{Dimensional Framework}

After conducting an extensive analysis of prior accountability studies, Ullmann (1995) indicated that one of the reasons for the inconsistent findings in previous research is the lack of theory. He argued that accountability models previously developed in prior studies are mis-specified because the relationship between organization strategy and accountability decisions is not included in the empirical tests. He proposed that firms use disclosures as a means to manage their relationships with their stakeholders and the external environment. This is the basic tenet of the stakeholder theory. He then developed a three-dimensional strategic framework consistent with the concept advanced in the stakeholder theory by Freeman. The three-dimension framework is useful to explain the correlations among disclosures and accountability as well as economic performance. The first dimension, stakeholder power, explains that an institution will be responsive to the intensity of stakeholder demands. For example, when stakeholders control critical resources, the organization is likely to react in a way that satisfies their demands. The second dimension, strategic posture, describes the mode of response the organization is likely to take concerning social demands. Entities employing an active posture try to influence their status by continuously monitoring their position with stakeholders, for example, by initiating social responsibility and accountability programs as well as disclosing their commitment. The third dimension, past and current economic performance, determines the relative weight of a social demand and the attention it receives. This dimension is relevant because it is conceivable that organizations suffering from low accountability may place economic demands ahead of social demands (Chan and Kent, 2003).

\subsubsection{Role Theory of Accountability}

Role systems theory was originally seen as a way to describe how organizations manage to inculcate or produce reliable behavior on the part of their members (Katz \& Kahn, 1998). Moreover, role theory outlined the critical place of individual interactions, it postulates the overiding purposes that should be anticipated in these relationships and emphasis the achievements that come upon that due to linkages arising from what people do as given responsibilities . According to Ferris et al (2000), the study indicated the areas that are highly stressed by people in terms of how the structures in the system stands relevant. Schlenker et al 2004 showed the work of linkages as Dose and Klimoski (2005), outlined how accountability was based on public perceptions and conclusions. Moreover, at its base, accountability implies the anticipation of an accounting, having to report or explain oneself to others in the future. İn role theory, the focal worker also anticipates facing auditing perhaps on shorter and recurring cycles. İn many ways, role theory explicates the essential components and relationships central to accountability.

\subsubsection{Mechanisms for Accountability}

Brown and Moore (2001) state that there is no single accountability structure that is right for all organizations. The needs of a transparent and standardized reporting and accounting mechanism for large scale service delivery, conflict with the requirements of providing the services and voice to those in need. Edwards and Hulme (1996) describe the need for standardized delivery mechanisms, structures that can handle large amounts of external funding, and systems for speedy - and often hierarchical -decision making but emphasize that effective performance as an agent of democratization rests on organizational independence, closeness to the poor, representative structures, and a willingness to spend large amounts of time in consciousness-raising and dialogue. Moreover, reporting alone is insufficient, as there must also be access to the information (Neligan, 2003). İn view of Ebrahim (2003), NGOs and other agencies already engage in disclosure and reporting by undertaking performance assessment, engaging in community participation and through self-regulation. There are various reporting requirements in law in many countries and these requirements are directed at providing accountability to the public at large and often require quite detailed information about finances, organizational structure and programs. Donors to NGOs also require performance assessments, and often employ experts and impose technical criteria to assess the data collection and analysis for 
particular programs. The NGOs are in turn accountable respective donors as a matter of prudence, as a matter of law and as a matter of ordinary morality (Brown \& Moore, 2001).

\subsection{Empirical Review}

A number of scholars have shown that the problems of adverse selection and moral hazard exist in the management of diverse outlets. Outlet/agency managers have an incentive to shirk and to misrepresent their abilities since the owner of the firm cannot easily differentiate the effect of manager behavior on outlet performance from the effect of exogenous factors (Brickley and Dark, 1987). Franchising scholars have found that one way that performance of outlets can be enhanced is through the provision of residual claimancy. However, the establishment of a hybrid organizational form does not eliminate all agency costs (LaFontaine and Kauffman, 1994). Roberts (2002) undertook a study to understand the determinants of corporate social responsibility disclosure using a sample of 80 companies drawn from a population of 130 major companies investigated in 1984, 1985 and 1986 by the Council of Economic Priorities (CEP). Roberts found that his measures of stakeholder power, strategic posture and economic performance are significantly related to levels of corporate social disclosure. The findings contribute to the knowledge on how organizations should manage their stakeholders using disclosures. However, the extent to which such disclosures are related to accountability remains debatable. For example, numerous studies from the 1980s through to 2000s report either no significant or negative relationship between disclosure and accountability (Patten, 2002). In another related study, Fogarty (1996) examined accountability standard-setting process and found that institutionalization, through the basis of separated procedures and the formal characteristics of assessment, enables the organizations to achieve tolerable decisional freedom. He further noted that the visibility of its processes, and the consequences of its outcomes, contributed to its critical dependence on legitimacy. Further, he analyzed the peer review process of firms as a mechanism utilized by them seeking to legitimize a largely self-regulatory industry. Studies by the National Audit Office (2001) regarding accountability practices indicated that accountability for joint expenditure requires the roles and responsibilities of partners, how their performance is to be measured and reported, and the accounting and audit arrangements to ensure propriety over public expenditure all need to be clearly set out and understood.

\subsection{Constituency Development Fund (CDF) in Kenya}

The Kenyan CDF history can be traced to the 2002 general election where the National government created a new fund where the 210 constituencies will be allocated 5 percent of the National revenue as devolved funds. The CDF was a system proposed by the NARC government on resource distribution to constituencies but has created powerful political bureaucracies in CDF projects administration and accountability. The CDF idea has its origin in Rwanda before borrowed by Uganda and than Kenya. In the proposed draft constitutions Kenya is to be divided into 47 counties based on districts created in 1992. In the draft the national government will be allocated 15 percent of national revenue in addition to the CDF politically then, there could be concern over the power that the governors and senators will have over MPs and over control of devolved funds. There will be 294 proposed constituencies with smaller units than the 47 counties. That means that one county could have more than four constituencies and therefore, that one governor will have larger constituency to control and govern than a member of parliament (MP). The county governments will consist of a county assembly and a country executive committee. The executive committee will implement the country and national laws.

\subsubsection{Functions of Constituency Development Funds}

Currently the CDF Act 2003 allow for establishment of a board of be known as the constituencies Development Fund Board (CDFB) as a body corporate with perpetual succession and a common seal and shall in its corporate name perform the following functions: sued and sue; take purchasing or otherwise acquiring, holding, charging or disposing of movables and immovable property; borrow money or making investments; and doing or performing all other acts or things for the proper performance of its functions (CDF Act 2003).

\subsubsection{Constituency Development Fund (CDF) National Board of Management (32 members)}

The CDF board currently is currently administered by a board of management consisting of:- the permanent secretary of the ministry of economic planning; the permanent secretary ministry of finance; the clerk of the National assembly; the attorney general; eight persons, qualified in matters relating to finance, accounting, engineering, economies, community development, or law, appointed by the minister; four persons, qualified in matters of relating to finance, accounting, engineering, economist, community development or law; the chief executive officer as ex-officio member and secretary to the board; the minister then shall appoint the chairperson of the board from amongst the eight persons 
appointed; four nominees, two of who shall be men. The total of 32 (thirty two) names taking into account regional balance of the people of Kenya; appoint nine (9) persons, at least one from the given entities and other selections based on the sex of the members within the board to be members of the board. The name for the persons proposed to be appointed as the chief executive officer to be submitted to parliament for approval before the appointments are made. (CDF Act, 2003).

\subsubsection{Composition of the Constituency Development Committee (CDC) 15 members}

The CDF Act 2003 provides for the establishment of CDF for every constituency, which shall be constituted and convened by the elected member of parliament, to have a maximum of fifteen (15) members, comprising of elected members of the legislature and the local authority participation, provisional administration participation as well as faith organizations representations besides other groups selecting their representatives. Persons representing religious organization in the constituency; two men representatives from the constituency; two women representatives from the constituency; one person representing the youth from the constituency; one person nominate form among the active NGOs in the area if numbers to aparticular level .

\section{Research Methodology}

This chapter comprises of the research design, the population of interest, the population sample, data collection instruments and the data analysis technique that will be used to establish the role of the audit committees in promoting corporate governance and accountability in constituency development fund management in Nairobi province.

\subsection{Research Design}

This is a descriptive survey supply aimed at establishing the role of audit committee in promoting corporate governance and accountability in constituency development fund management (CDF) in Nairobi Province in Kenya. A descriptive study is concerned with finding out what, where and how of a phenomenon.

\subsection{Target Population and Sample}

This is a case study of the Constituency Development fund (CDF). The population of interest of this study will be CDF units at the Nairobi province. The Nairobi constituencies residents numbering and target of 80 (eighty) ten from every constituency of Nairobi. This will be a good representative of the residents since it will be a sizeable than population. They will be selected from both the list of employees of the Constituency Development Fund committee and Nairobi populace. The study being a case study implies that data will be collected from 8 (eight) constituency of Nairobi who will represent all the other 210 constituencies in the CDF in Nairobi province. Nairobi province is a cosmopolitan with presumed knowledgeable staff, centre of CDF disbursement and with uniqueness in character compared to other provinces. This therefore means that a case study method will be used.

\subsection{Data Collection}

İn order to identify the role the audit committee can play in promoting corporate governance and accountability in the constituency development fund management in Nairobi in Kenya, self-administered drop and pick questionnaires will be distributed among senior employees currently employed by the CDF and Nairobi residents. Questionnaire is designed to identify the role the audit committee can play in promoting corporate governance and accountability in the CDF management in Nairobi Province. The study being a case study means that respondents will be selected from various 8 constituencies of Nairobi and the CDF and administered with the questionnaire. The staff in the department includes managers and other senior staff in the ranks of management in the CDF. Structured questionnaires will be used as the main data collection instrument. The questionnaires have both open and close ended questions. The closeended questions provide more structure responses to facilitates tangible recommendations. The open-ended questions provide additional information that may not have been captured in the close-ended questions. Secondary data sources will be employed through the use of previous documents or materials to supplement the data received form questionnaires and information from interviews.

\subsection{Data Analysis Procedures}

Qualitative data will be analyzed using qualitative analysis while SPSS will used to analyses the quantitative data. Qualitative data analysis will seek to make general statements on how categories or themes of data are related Mugenda and Mugenda (2003)). The qualitative analysis will be done using content analysis. Content analysis is the systematic qualitative description of the composition of the objects or materials of the study (Mugenda and Mugenda 
2003). İt involves observation and detailed description of objects, items or things that comprise the sample. Descriptive statistics will be used to summarize the data. This includes percentages and frequencies. Tables and other graphical presentations as appropriate will also be sued to present the data colleted for ease of understanding and analysis.

\subsection{Reliability and Validity of Primary Data}

The reliability and validity of data collected for research will be controlled through formulation of relevant research question by considering the research questions that expresses a relationship between variables the questions is stated in an unambiguous form and the questions that might be tested empirically (Black 1993); choosing the appropriate data collection method that suits the research questions and using a sampling technique that ensures that the sample is representative and minimizes bias.

\section{Data Analysis and Findings}

This chapter set to give a detailed analysis of data collected. Data was collected using the audit committee questionnaire and checked with audit committee reports included in the capital market authority CMA 2008. Collected data was analysed in order of the research questions to achieve the objective of the study.

\subsection{General information about the respondents}

Table 1 presents data on the number of constituencies in Nairobi having no audit committees and who's respondents wished establishment of the audit committee to instill corporate governance and accountability in the management of CDF. İt can be seen that 49 (89.1 percent) of the 55 respondents recommended for establishments of audit committee in their respective constituencies. The questionnaire was addressed to other CDF management committee ad those who reside in respective constituencies of Nairobi.

Table 1: Constituencies without audit committees and wished to have one established.

\begin{tabular}{|l|c|c|c|c|c|}
\hline Constituency & $\begin{array}{c}\text { No. of respondent } \\
\text { target } \\
\text { in the sample }\end{array}$ & $\begin{array}{c}\text { No. recommended A.C } \\
\text { established }\end{array}$ & $\begin{array}{c}\text { No. not } \\
\text { recommended } \\
\text { A.C established }\end{array}$ & $\begin{array}{c}\text { Total } \\
\text { respondents }\end{array}$ & $\begin{array}{c}\text { Parentage } \\
\text { respondents per } \\
\text { constituency }\end{array}$ \\
\hline Dagoreti & 10 & 5 & 1 & 6 & $60 \%$ \\
Embakasi & 10 & 6 & 0 & 6 & $60 \%$ \\
Kamukunji & 10 & 5 & 2 & 7 & $70 \%$ \\
Kasarani & 10 & 8 & 0 & 8 & $80 \%$ \\
Langata & 10 & 6 & 1 & 7 & $60 \%$ \\
Makadara & 10 & 6 & 1 & 8 & $70 \%$ \\
Starehe & 10 & 7 & 1 & 7 & $80 \%$ \\
Westlands & 10 & 6 & 6 & 55 & $70 \%$ \\
\hline Total & 80 & 49 & 0 & $68.75 \%$ \\
\hline
\end{tabular}

Source: CDF audit committee questionnaire.

Table 1 also shows that the respondents are evenly distributed across different constituencies in Nairobi. Ten (12.5 percent) of the respondents were chosen from Nairobi's eight constituencies. All the sample (of ten) respondents did not respond. 6 (7.5 percent) from Dagoreti, Embakasi and Langata 7 (8.75 percent) from Kamukunji, Makadara and Westlands and 8 (10 percent) form Kasarani and Strarehe. 55 (89.1 percent) respondent the questionnaire with 6 (10.9 percent) did not recommend for establishment of audit committee in their respective constituencies.

\subsection{The roles of the audit committees}

The main responsibility of the audit committees if established, it to oversee the planning CDF projects, appraisals of the $\mathrm{CDF}$ projects, receiving feedback of CDF projects, ensuring accountability of CDF projects, ensuring accounting policies are maintained in CDF records, enforcing proper bookkeeping records and persuing CDF project feasibility studies. It is clear from the table 2 that 93 percent $(45.1+47.9)$ of the respondents indicated that the above six roles will be played by the audit committees if established to instill corporate governance and accountability in the management of. 
Table 2: The role audit committee can play in promoting governance and accountability in CDF management

\begin{tabular}{|c|c|c|c|c|c|c|}
\hline Responses & Responde & gree & & & & \\
\hline & $\begin{array}{l}\text { Strongly } \\
\text { agree } 5\end{array}$ & Agree & Neutral & Disagree & $\begin{array}{l}\text { Strongly } \\
\text { disagree }\end{array}$ & $\begin{array}{l}\text { Total } \\
\text { respondent }\end{array}$ \\
\hline Planning CDF projects & 42 & 10 & 2 & 1 & 0 & 55 \\
\hline Appraisals of CDF projects & 09 & 41 & 3 & 2 & 0 & 55 \\
\hline Receiving feedbacks & 29 & 22 & 1 & 3 & 0 & 55 \\
\hline Accounting Policies adherence & 40 & 13 & 0 & 2 & 0 & 55 \\
\hline Bookkeeping adequacy & 10 & 42 & 1 & 2 & 0 & 55 \\
\hline Feasibility & 19 & 30 & 2 & 4 & 0 & 55 \\
\hline Total & 149 & 158 & 9 & 14 & 0 & 330 \\
\hline Percentage & 45.1 & 47.9 & 2.72 & 4.24 & 0 & 100 \\
\hline
\end{tabular}

Source: CDF Audit committee questionnaires

4.3 Role of audit committees in enhancing efficiency and effectiveness performance management

The main responsibilities an audit committee can play in enhancing efficiency and improve management performance in CDF Nairobi Province (if established) scored highly 92.4 percent $(28.3+61.1)$ of he respondents in average table 3 recommended the as follows:- to be vigilant body as an effective overseers of financial reporting processes and internal controls, 91 percent, to review and make recommendations of management programs established to monitor compliance with the code of conduct 91 percent to consider the appointing to the internal auditor 91 percent, to consider the appointing of the internal auditor 91 percent, discuss with external auditor before he audit commences 89 percent, review quarterly half yearly and years ends financial statements 93 percent, review any communication between external auditor and management 91 percent, consider any relate party transactions that may arise within management 92 percent, consider major findings of internal investigations and management responses 92 percent. Have explicit authorities to investigate any matter within the CDF manage 92 percent, have full access of CDF institutions. 
Table 3: Responsibilities of audit committees

\begin{tabular}{|c|c|c|c|c|c|c|}
\hline Responses & 5 & 4 & 3 & 2 & 1 & Total \\
\hline $\begin{array}{l}\text { To be informed and be vigilant and effective overseers of the CDF financial reporting } \\
\text { process and internal controls. }\end{array}$ & 20 & 31 & 1 & 3 & 0 & 55 \\
\hline $\begin{array}{l}\text { To review and make recommendations on CDF management programs established to } \\
\text { monitor compliance with the code of conduct }\end{array}$ & 10 & 41 & 2 & 2 & 0 & 55 \\
\hline To consider the appointing of the CDF internal auditor & 10 & 41 & 2 & 2 & 0 & 55 \\
\hline Discuss with the external auditor before the audit commences for CDF project & 10 & 39 & 3 & 3 & 0 & 55 \\
\hline $\begin{array}{l}\text { Review the quarterly, half yearly; and year and CDF financial statements of their } \\
\text { consistency }\end{array}$ & 20 & 33 & 1 & 1 & 0 & 55 \\
\hline Review and communication between external auditor and CDF management & 11 & 40 & 2 & 2 & 0 & 55 \\
\hline Consider any related party transaction that may arise within CDF management & 10 & 42 & 2 & 2 & 0 & 55 \\
\hline $\begin{array}{l}\text { Consider major findings of CDF internal investigations and CDF management } \\
\text { Reponses }\end{array}$ & 40 & 12 & 1 & 2 & 0 & 55 \\
\hline Have explicit authority to investigate any matter within the CDF & 13 & 29 & 1 & 2 & 0 & 55 \\
\hline Have full access to CDF information & 23 & 30 & 2 & 1 & 0 & 55 \\
\hline $\begin{array}{l}\text { Obtain external professional advice and to invite outsiders with relevant experience to } \\
\text { attend the CDF projects implementations and evaluation if any. }\end{array}$ & 12 & 40 & 2 & 1 & 0 & 55 \\
\hline Total & 179 & 388 & 16 & 22 & 0 & 605 \\
\hline Percentage & 29.6 & 64.1 & 2.6 & 3.6 & 0 & 100 \\
\hline
\end{tabular}

Source: CDF Audit committee questionnaire.

To investigate 92 percent obtain external professional advice and to invite outsiders with relevant experience to attend the project implementation and evaluation 92 percent. 2.6 percent where neutral in their view on the role audit can play wile 3.6 percent disagreed. Table 3 clearly indicated that the audit committees can provide non-audit services on top normal audit services. The audit committees should therefore monitor these non-audit services.

\subsection{Composition and Membership of Audit Committees}

To ensure the independence of the members of the audit committees and to avoid conflict of interest, all audit members should be appointed by the board of directors and not by the management or members of parliament of that constituency. The CMA guidelines required that the audit committee made up of at least three independent and non executive directors who shall report to the board. Having independent non executive member in the audit committee is a primary and fundamental requirement that was addressed in a trade way

Table 4: Number of directors recommended auditing committee in CDF

\begin{tabular}{|l|l|l|}
\hline Number of members & Number of respondents & Percentages \\
\hline 3 & 27 & $48 \%$ \\
4 & 14 & $26 \%$ \\
5 & 4 & $7 \%$ \\
6 & 6 & $11 \%$ \\
7 & 2 & $4 \%$ \\
14 & 2 & $4 \%$ \\
\hline TOTAL & 55 & $100 \%$ \\
\hline
\end{tabular}

Source: Audit committee questionnaire. 
Table 4 clearly indicates 48 percent of the respondent had suggested less than 3 the minimum number of independent non-executive directors. 48 percent had suggested for 3 non executive more than 3 independent non executive directors.

\subsubsection{Meetings of audit committees}

İn 1998, Arthur Levitt, chairman of the SEC remarked that an ideal audit committee is the one that meets 12 times a year before each board meeting. İn this study, two of the respondents (4 percent) complies with that. The greater number of respondents recommended quarterly audit committee meetings (63 percent) of the remaining İ İ percent recommend twice or thrice per year, another İ İ percent meet thrice, 7 percent meet six times while the remaining 4 the remaining portion do it other wise. İt seems less frequent conducts of business should be enough despite times of unavoidable happenings requiring to be addressed by the audit teams, Which is around 3.8 periods.

Table 5 Number of meetings of recommended for CDF audit committees

\begin{tabular}{|l|l|l|}
\hline Responses & Number of respondents & Percentages \\
\hline 2 & 6 & $11 \%$ \\
3 & 6 & $11 \%$ \\
4 & 35 & $63 \%$ \\
5 & 9 & $0 \%$ \\
6 & 4 & $7 \%$ \\
7 & 0 & $0 \%$ \\
8 & 2 & $4 \%$ \\
9 & 0 & $0 \%$ \\
10 & 0 & $0 \%$ \\
11 & 0 & $0 \%$ \\
12 & 2 & $4 \%$ \\
\hline Total & 55 & $100 \%$ \\
\hline
\end{tabular}

Source: CDF audit committee questionnaire.

From able 5 most of the audit committees should meet on average or two hours ( 85 percent). Eleven percent recommended for three hours while only 4 percent should meet for four hours. Te average audit committee meeting should be out of 2.2 hours.

4.5.2 Recommended operations of audit committees

Most of the questions in the CDF audit committee questionnaire focused on the operations of the audit committees. A detailed analysis of recommended operations of CDF audit committees if established follows below:-

\subsubsection{Establishing audit committee charter and guidelines}

Table 6 indicates recommendations as a good trend that all the 55 respondents (100 percent) should have a developed or CDF audit committees. However in their recommendations, the respondents (56 percent) recommended their charters to be updated annually, while the remaining 44 percent indicated that their update only on a need basis (Table 7) and therefore, not necessarily annually.

Table 6 Written charters

\begin{tabular}{|l|l|l|}
\hline Responses & Number of respondents & percentages \\
\hline Yes & 55 & $100 \%$ \\
No & 0 & $0 \%$ \\
\hline Total & 55 & $100 \%$ \\
\hline
\end{tabular}

Source: $C D F$ audit committee questionnaire 
Table 7: Annual updating of the CDF charter.

\begin{tabular}{|l|l|l|}
\hline Responses & Number of respondents & Percentages \\
\hline Yes & 31 & $56 \%$ \\
No & 24 & $44 \%$ \\
\hline Total & 55 & $100 \%$ \\
\hline
\end{tabular}

Source: $C D F$ audit committee questionnaire

\subsection{Conducting meetings prior to the start of the audit}

The CDF audit team shaves to evaluate and ascertain the parts prone to risks in CDF which might involve further discussions with auditing teams for needed years of the CDF audit plan together with the resolution of prior year CDF issues. As indicated in table 8, agreat portion of participants $(89 \%)$ recommended for establishment of CDF auditing organization to conduct their mandate and assess all sectors in the constituency but at some level with other interested auditing stakeholders. The planning events a critical as bring out required concerns about CDF risky and material sectors of the constituency. However 11 percent indicated the CDF audit committee does not need to conduct any such meetings.

Table 8. External auditors conducting meetings with CDF audit committee prior to the start of the audit.

\begin{tabular}{|l|l|l|}
\hline Responses & Number of respondents & percentages \\
\hline Yes & 45 & $89 \%$ \\
No & 10 & $11 \%$ \\
\hline Total & 55 & $100 \%$ \\
\hline
\end{tabular}

Source: CDF audit committee questionnaire

It was recommendable for CDF auditing groups review the work of the out come of directors functioning and auditors part on what directors deeds were.

\subsection{Discussion of the performance of the finance and accounting department}

The CDF performance of the finance and accounting department is mainly not the responsibility of CDF auditing teams. A small percentage (19\%) recommended CDF revelations highliting performance about the subject of discussion to a very great effect but 41 percent recommended the discusion to a large extent, 26 percent to some extent, while 14 percent don't discuss it at all.

Table 9 discussion of the performance of accounting and finance department

\begin{tabular}{|l|l|l|}
\hline Extent of discussion & No. respondents & Percentages \\
\hline To a very large extent & 11 & $19 \%$ \\
To a large extent & 22 & $41 \%$ \\
To some extent & 14 & $26 \%$ \\
Not at all & 8 & $14 \%$ \\
\hline Total & 55 & $100 \%$ \\
\hline
\end{tabular}

Source: CDF audit committee questionnaire:

4.8 Monitoring of the nature and extent of non-audit services performed by the external auditor by the audit committees

When the external auditors provide a lot of other non-audit services on top of normal audit services it may erode their independence. The CDF audit committees as recommended by respondents should therefore monitor these non-audit services. However as table 10 recommended 52 respondents recommended of CDF audit committees to monitor these services while 48 percent did not. However all the respondents recommended that the external auditors and the internal auditor should have direct access to the CDF audit committees, which should greatly increase their independence? 
Table 10: audit committees to monitor non-audit services in CDF

\begin{tabular}{|l|l|l|}
\hline Responses & Number of respondents & percentages \\
\hline Yes & 29 & $52 \%$ \\
No & 26 & $48 \%$ \\
\hline Total & 55 & $100 \%$ \\
\hline
\end{tabular}

Source: $C D F$ audit committee questionnaire

\subsection{Audit committees engaging outside experts}

The CDF audit committee should obtain external professional advise and to invite outsiders with relevant experience to attend meetings if necessary. From table 11, 70 percentage of the respondents indicated that the experts should be engaged while 30 percent recommended that they should have never had to engage in CDF corporate governance, though they recommended having the provision in their charters.

Table 11: CDF audit committees engaging experts

\begin{tabular}{|l|l|l|}
\hline Responses & Number of respondents & Percentage \\
\hline Yes & 39 & $70 \%$ \\
No & 16 & $30 \%$ \\
\hline Total & 55 & $100 \%$ \\
\hline
\end{tabular}

Source: $C D F$ audit committee questionnaire

\subsection{Audit committee reports}

Since the CDF audit committee will serve as a guard on the CDF funds assets and projects of stakeholders about the authenticity of funds assets and projects of CDF to the CDF stakeholders. Positive reporting is very elementary to the rquired efficiency. Despite how good the work of the audit committee in the CDF will not be able to benefit from their efforts if the CDF boards are not informed of their findings. Lines of reporting between the CDF management boards should be based on the specific tasks and mandate for the CDF audit teams. Communication channels between the CDF audit committees and the audit committee reports to the main boards on a regular basis.

Table 12 shows that 89 percent of the respondents recommended report to the CDF stakeholders.

Eleven percent does not recommend CDF audit committees finding to report to stakeholders.

Table 12 audit committee reporting to the shareholder on its activities and findings

\begin{tabular}{|l|l|l|}
\hline Responses & Number of respondents & Percentages \\
\hline Yes & 49 & $89 \%$ \\
No & 6 & $11 \%$ \\
\hline Total & 55 & $100 \%$ \\
\hline
\end{tabular}

Source: CDF audit committee questionnaire

\subsection{Relationships with management internal auditor and external auditor}

The CDF audit committee questionnaire included questions to capture the relationships within the CDF environment captured the interactions among the elements within the CDF.

\subsubsection{Extent to which their relationship will be positive}

Table 13 indicates the extent to which the respondents perceived the relationships between the audit committees and the CDF management, internal and external auditors as being positive. As can be seen from the table, depicted the interactions with the management at a good level (41\%), which is acceptablet as $59 \%$ indicated that it was positive to a large extent. This is commendable as audit committees can only be effective when relationship is positive. 
Table 13: levels among the CDF stakeholders

\begin{tabular}{|l|l|l|}
\hline level & No. Of participants & Percentage \\
\hline To a very large extent $(60 \%)$ & 23 & 41 \\
To a large extent $(50 \%)$ & 32 & 59 \\
To some extent $(40 \%)$ & 0 & 0 \\
Not at all( below $40 \%)$ & 0 & 0 \\
\hline Total & 55 & 100 \\
\hline
\end{tabular}

Source: CDF audit committee questionnaire

\subsection{Independence of audit committees}

For the CDF audit committees to be effective, it was suggested by respondents that it must be independent and especially resist influence from the CDF management. The CDF audit committees may find it necessary or useful to hold separate private meetings with both the internal and external auditors with no CDF management present. Private meeting(s) would help to ensure a free and frank exchange where the expression of views might otherwise be restricted. Private meeting(s) with CDF management in absence of the auditors can also be helpful. As shown in table 14 , a great number (74\%) indicated that the CEO board attended auditing teams sessions on official invitations as a smaller number (26\%) indicated the times attendance was by free will.

Table 14: CEO attending meetings on invitation only

\begin{tabular}{|l|l|l|}
\hline Responses & No. of respondents & Percentage \\
\hline Yes & 41 & $74 \%$ \\
No & 14 & $26 \%$ \\
\hline Total & 55 & $100 \%$ \\
\hline
\end{tabular}

Source: $C D F$ audit committee questionnaire

\subsection{Achievement and challenges of CDF audit committees}

The achievement of CDF audit committees if established in CDF governance was explained by key queris. There was one question on effects of CDF auditing committees should have on the internal auditors and whether the CDF audit committees will increase reliability of financial statements. There were also open questions on the major achievements and challenges the $\mathrm{CDF}$ audit committees likely to face.

\subsection{Extents to which audit committees would improve the effectiveness of internal auditors}

The performance and efficiency of the CDF internal audit department was suggested to be the responsibility of the CDF audit committees. As indicated on table 15 seventy six percent of the respondents indicated that the CDF audit committees will improve the over all performance of the concerned auditing groups while a lesser number (26\%) indicated that the change will be there to some extent. The importance of auditng as a major duty for CDF auditing committee be one of among the achieved goals.

Table 15 having CDF audit committee will improve the efficiency and effectiveness of the internal auditors

\begin{tabular}{|l|l|l|}
\hline Extent of believe & No. respondents & Percentages \\
\hline To a very large extent & 41 & $76 \%$ \\
To a large extent & 14 & $26 \%$ \\
To some extent & 00 & 0 \\
Not at all & & 0 \\
\hline Total & 55 & 100 \\
\hline
\end{tabular}

Source: CDF audit committee questionnaire

4.14.2 Extent to which CDF audit committees will increase the acceptance of their results

As shown on table 16 most of the respondents (67 percent) believe that the CDF audit committees will increase the reliability of the financial reports to a very great extent. The remaining (33 percent) indicated that the CDF audit committees will increase the reliability to a large extent. 
Table 16 extent to which CDF audit committees will increase the acceptance of financial reports

\begin{tabular}{|l|l|l|}
\hline Extents of reliability & No. of respondents & Acceptance level \\
\hline Very large extent $(60 \%-100 \%)$ & 37 & $67 \%$ \\
To a large extent $(50 \%-60 \%)$ & 18 & $33 \%$ \\
To some extent $(40 \%-50 \%)$ & 0 & 0 \\
Not at all $(0 \%-40 \%)$ & 0 & 0 \\
\hline Total & 55 & $100 \%$ \\
\hline
\end{tabular}

Source CDF audit committee questionnaire

\subsection{Major Audit Committee Achievements}

The main success witnessed was within the CDF auditing. It was found that a majority of the CDF audit committees will encourage matters tackled by CDF authorities, which wastes no time. İt will enhance independence of the auditing group. Other achievements suggested included significant improvement in corporate governance practices, improved risk management and control processes clarifying the role of internal audit vis a vis CDF policy setting, forcing CDF management to pay greater attention to formal control, enhancing CDF processes dealing with audit hence cutting down on costs.

\subsection{Major challenges likely to face the CDF audit committees}

Most respondents indicated that there is likely major challenges to CDF audit committees if formed as rapidly changing environment increased local and international regulations, that CDF audit committee will be a new concept and setting its boundaries will be an issue, dominant senior CDF management, chiefs, MP chiefs, influence in CDF management most likely to interfering with work of CDF audit committees if not closely watched and that they are to be asked to take responsibilities over CDF governance and financial reporting while their involvement should be minimal.

\subsection{Reasons why CDF have not established audit committees}

There was one question on why all CDF management had failed to established CDF audit committees (all respondents indicated the failure to frequent CDF management they had not adequately internal control measures interference from influential local persons the impact of the MP on CDF management and ignorance of the CMA guidelines.

\section{Discussions}

\subsection{Operations of Audit Committees}

From the analysis it was observed that all eight constituencies of Nairobi province have not established audit committees. Neither the location of the constituency nor the size was seen to be determinants of whether a constituency should establish an audit committee or not. İn a similar study conducted in Brahmin, Joshi (2004) had concluded that the size of the company and the audit firm whether international or local influence as audits committees in Kenya were established as a result of the CMA guidelines i.e. not voluntarily. All eight constituencies of Nairobi that responded to the questionnaire did not have literature on the need for audit committee charter. The key is that every constituency should develop a tailor made charter for the audit committee and that every constituency audit committee and that the charter should be updated annually to fit changing environment and fit to changing situations. Eighty nine percent respondents recommended audit committees to be conducting business involving presence of outside participants before the final auditing which determines the outcome of the management letter at same time paving way for other stakeholders to monitor the extent of non-audit services performed by the external auditors. Studies that have been undertaken on oversight responsibilities revolved mainly in the areas of financial reporting auditing and overall corporate management.

\subsection{Relationship with management internal and external auditors}

In this study the relationship with CDF management internal and external auditors should be positive to a large extent. CDF management and auditors should correspond with the audit team using modern channels of communication. The auditing group should be not influenced by the CDF officials and a greater number (74\%) indicated recommended that the CEO's should attend the CDF auditing sessions when there was need to. Empirical $f$ ind ings indicated that the 
level of achievement by these auditing teams depended on their interactions as they worked together.The CEO should be the main person communicating matters relating to the concern and can ensure quick actions on audit committee request. The chairperson of the $\mathrm{CDF}$ audit committee should have the sensitivity to know when to bring the CEO in to the committees' deliberations and the strength to stand up to him when the audit committee so desires to have business done other wise. Some findings in USA the concluded that effectiveness of the committees were subject to how official invitation of the CEO were done in terms when to attend and when not to. İn another study Haka and Chalos had found evidence of agency conflict between management and the audit committees in CDF corporate governance and accountability in the areas studied appear to have been forgotten with a response at high level $(76 \%)$ showing attendance by the executive officer by invitation was suitable. Relationship was a critical element among stakeholders of the auditing teams for it gurantees success and achievement.

\subsection{Achievements and challenges of CDF auditing teams}

Finding led to the conclusions that the main achievement of the audit committee was the provision of the internal audit with an effective flow of information leading to timely feedbacks at all times in a cost effective manner to enhance its independence. Audit committees will also increase the reliability of the financial statement to a very large extent. Literature, however, is divided on the achievement of audit committees. A study by Guy (2004) found out that only 15 percent of executive director's of TTSE 100 companies believe audit committees were vital in order to achieve sound corporate governance. However A/CPA considers audit committees as vital in improving internal controls. Literature gives the challenges facing a result of their report being included in the many stakeholders. Other challenges included the regular discharge of their mandate as perceived by stakeholders like the audit groups. The major and apparent challenge was the unpredictable legal environment that changes very oftenly with new requirements from time to time without prior notices to the affected parties. The respondents indicated that the major challenges will be changes in legal and operating environment increased liability and the problem of setting the boundary between the audit committee and the CDF management and the perceived influence the area MP and the councilors have on the CDF operations.

\section{Conclusions}

All the listed companies in Nairobi stock exchange (NSE) meet the CMA requirement in terms of the composition membership and independence of audit committee members. CDF in establish audit committee have audit committee charters in order to increase their independence and those of internal and external auditors. The relationship of the CDF audit communities with CDF managerial internal and external auditors should be cordial to a large extent. For the all constituencies in Nairobi province the reason given was frequent CDF management changes and lack of legal framework. The audit committee is highly likely to promote corporate governance and accountability in management of CDF in not only in Nairobi province but also in Kenya if established in line with CMA guideline.

From the analysis it was observed that all the eight constituencies of Nairobi province have no established CDF audit committees. All the responded to the questionnaire recommended CDF to have audit committee charters where 56 percent recommended annual update of those charters. A big number $(89 \%)$ recommended CDF auditing teams to have scheduled meetings together with external auditors before the yearly exercise that reviews the management letter. $58 \%$ recommended of audit committees to monitor the extent of non-audit services performed by the external auditors in CDF. A majortity showed that the CDF auditing teams to be meeting. With the number of committee members as required by CMA guidelines with all of them are having an average 4.3 members per committee. Members and the CDF audit committee chairperson should be appointed by the management, will increase their judgemental prudence from the CDF functiong. The CDF audit should have enough experience and exert with all knowledge, industry experience and financial experts to be effective in their role. The average number of CDF audit committees meetings should be 3.8 per year average 2.2 hours. The audit committee members should be in charge of setting the agenda and should use the charter as a guide to a very large extent. Fifty six percent of CDF audit committee recommended them to be assessing the CDF management performance annually and the CDF stakeholders to be mainly carrying of the CDF assessment.

The relationship with CDF management internal auditor and external auditors will be possible to large extent. CDF management and auditors should correspond with the audit committees involving moden net works of communication. CDF auditing teams should be free from the influence by CDF board's officials with above average response (74\%) that recommended chief executives to be attending CDF audit committee meeting on invitation. 
The major achievement of the CDF audit committees should be providing the internal audit with a communication channels ensuring that the audit issues raised from part of the audit teams are addressed immediately to enhance its independence. CDF audit committees will also increase the reliability of the financial statements to a very large extent. The major challenges anticipated to CDF audit committees' establishment are changes in legal and operating environment problem of setting the boundary between the CDF audit committees and CDF management and control influence of the MP and councilors from the CDF management.All the respondents indicated frequent changes in CDF management, lack of proper legal framework on CDF fund management influence of local MP and councilor's lack of string internal control and ignorance of CMA guidelines. Majority of respondents to the audit committee questionnaire gave the following as the main roles to be played by audit committee to promote governance and accountability to oversee the planning of CDF projects appraisals receiving feedbacks, ensuring accountability, accounting policies CDF projects and carrying out project feasibility studies.

Most respondents (92 percent) recommended the following as the main responsibilities of audit committees towards enhancing efficiency and management in CDF Nairobi province; to be vigilant body as an overseer of internal control, reviewing and making recommendations on CDF management programs and monitor compliance with the code of conduct consider the appointment of the internal auditors, discuss with external auditors before the audit commerce reviewing quarterly, half-yearly and year-ends financial statement review any communication between external auditors and CDF management consider major findings of internal investigations and CDF management responses, have explicit authority to investigate any matter within the CDF management have full access to information obtain external professional advice and invite outsiders with relevant experiences to attend the CDF project implementation and evaluation.

\section{Acknowledgements}

We acknowledge worksmart international company limited staff for their tireless efforts in accomplishing this survey.

\section{References}

A İCPA (2004), Conducting audit committee self-evaluation guideline and question, audit Committee Effectiveness Centre.

Atwood Frank, Auditing, Pitman Publishing, London.

Auditor General of Canada (1999), Involving Others in Governing - Accountability at Risk, available at: www.oagbvg.gc.ca/domino/reports.nsf (accessed 14 May 2008).

Auditor General of Canada (2000), Managing Departments for Results and Managing Horizontal Issues for Results, available at: www.oag-bvg.gc.ca/domino/reports.nsfaccessed 14 May 20080.

Bandura, A. (2001), Social Cognitive Theory: An Agentic Perspective, Annual Review of Psychology, Vol. 52, pp. 1 26.

Barrett, P. (2001), E-government: Transforming Public Administration, Address to İnstitute of Public Administration, Canberra, 30 April 2001, available at: www.anao.gov.au (accessed 14 May 2002).

Bean James W. (1999), the audit committee's roadmap A İCPA.

Bebbington, J., and Gray, R., (1993), Corporate Accountability and the Physical Environment: Social Responsibility and Accounting beyond Profit, Business Strategy and the Environment, Vol. 2 No.2, pp. 1-11.

Bell, J. (1993), Doing a Research Project, Beckingham, Open University Press.Brickley, D. and Dark, R. (2003), NGOs Must Become More Accountable, Australian Financial Review, 22 July.

Blue ribbon committee (BRC) (1999), Improving the effectiveness of corporate audit committee, New York.

Braiotta Louis (1999), The audit committee handbook, $3^{\text {rd }}$ Ed John Wiley and sons İnc New York.

Brown, D.L., and Moore, M. H., (2001), Accountability, Strategy, and International Non government Organizations, non profit and voluntary sector quarterly, Vol. 30 No. 3 pp. $569-587$ 
Chan, D. D. \& Kent, G. R. (2003). Accountability in the Management of Human Resources. Englewood Cliffs, NJ: Prentice-Hall.

CMA (2002), Guidelines on corporate governance practices by public listed companies in Kenya.

Constituency Development Act 2003

Cooper D. R (1998), Business Research Methods, $6^{\text {th }}$ edition, İrwin McGraw Hill N. Y.

Coopers \& Lybrand (1995), Audit committee guide, Coopers \& Lybrand.

Cronin, D., and O’Regan J., (2002), Accountability in Development Aid: Meeting Responsibilities, Measuring Performance- Feignstain İnternational Center, Dublin.

Dezoot F.T. et al (2002) audit Committee effectiveness: a synthesis of he empirical audit committee literature , Journal of accounting literature' Vol. 21 PP $38-75$.

Dose, J. J. \& Klimoski, R./ J. (2005). Doing the Right Thing in the Workplace: Responsibility in the face of Accountability. Employee Responsibilities and Rights Journal, Vol. 8

Ebrahim, a. (2003), Accountability in Practice: Mechanisms for NGOs, World devilment, Vol. 31 No, pp. 813-29.

Ebrahim, A. (2005), Accountability Myopia: Losing Sight of Organizational Learning, Nonprofit and Voluntary Sector Quarterly, Vol. 34 No. 1, pp. 56-87.

Edwards, M. (2003), Participatory Governance into the Future: Roles of the Government and Community Sectors, Australian Journal Public Administration, Vol. 60 No. 3pp. 78-88

Edwards, M. and Hulme and D. (eds) (19960. Non-governmental Organizations - Performance and Accountability: Beyond the Magic Bullet, Earthscan, London.

Eisenhardt, K. M. (1989). Control: Organizational and Economic Approaches, Management Science, Vol. 14 No. 1 , pp. $57-74$

Ferris, G.R., Mitchell, T.R., Canavan, P. J., Frink, D.D., \& Hopper, H. (2000). Accountability in Human Resource Systems. Human Resource Management Review Vol. 14 1-17

Fogarty, T.J. (1996). Financial Accounting Standard Setting as an Institutionalized action field: Constraints, opportunities and dilemmas, Journal of Accounting and Public Policy, Vol. 11 (4): 331-356.

Fowler A.F., (1996), Assessing NGO Performance. Difficulties, Dilemmas, and a Way Ahead, İn Edwards, M and Hulme, D. (Eds), Beyond the Magic Bullet. NGO Performance and Accountability in the post Cold War World, Connecticut, Kumarian Press.

Goddard Andrew et al; Audit committee, Cadbury code and audit fees; an empirical Analysis of UK companies, Managerial Auditing Journal MCB University press vol. `'15 no 7 pp 355-371.

Gray, R., Bebbington, J., and Collison, D., (1970), NGOs, Civil Society and Accountability: Making the People Accountable to Capital, Accounting, Auditing \& Accountability Journal, Vol. 19 No. 3, pp319-348.

Graziano Cheryl (2004), Audit committee step up, corporate Board Member.

Guthire, J., and Parker, L.D., (1990), Corporate Social Disclosure Practice: A Comparative İnternational Analysis, Advances in Public İnterest Accounting, Vol. 3, pp. 159-176.

Guy and Burke (2001), Audit committees; A guide for Directors, Management and consultants,

Hair, J.F. et al (1992) Multivariate Data Analysis (3rd ed) New York: MacmillanJensen, M.C., \& Meckling, W. H. (1996). Theory of the Firm: Managerial Behaviour, Agency Costs and Ownerships Structure Journal of Financial Economics Vol. 3, 305-360.

Herdman R. K.(2002), Making Audit Committee more effective, Tulane Corporate law institute New Orleans.

Jensen M. C. et al (1976), theory of the firm: managerial behaviour, agency costs and ownership structure, Journal of financial economics Vol. 11 pp $305-360$. 
Joshi PL et al (2004), A Study of the audit committee function in the Brahmin; University of Brahmin, Management Auditing Journal, Vol. 19 - no. 7.

Kalbers LP et al (1993) Audit committee effectiveness: an empirical investigation of the contribution of power Auditing a journal of practice and theory 12, $24-24$.

Katz, D., \& Kahn, R.L. (1998). The Social Psychology of Organizations (2nd ed.) New York: Wiley.

Keohane, R.O., (2002), Commentary on the Democratic Accountability of Non-governmental Organizations, Chicago Journal of İternational Law, Vol. 3 No. 2, pp. 477-479.

Kimani, K. (2008), Resource Allocation and managerial Accountability in Kenya, NEMA Appraisal Report, Nairobi

Kovach, H., Neligan, C., and Burall, S., (2003), Power without Accountability Executive Summary of the Global Accountability Report, (Electronic), www.oneworldtrust.org/htmlGAP/[Accessed:28 April 2008].

KPMG (1999), Corporate Governance: A guide to corporate accountability, KPMG Audit Committee İnstitute

KPMG, 2001 www. KPMG. Com/aci/surveys.htm.

Ladd, J.A. (1996). The Empowerment Process: İntegrating Theory and Practice. Academy of Management Review, 13 471-482.

Marshall, M., (2002), Legitimacy and Effectiveness; Civil Society Organizations' Role in Good Governance, Paper Presented at the Poverty Reduction Strategies Forum, Baden, Austria, October 29-November 1,2002.

McCarthy, A., (2001), Accountability 'Vital' if NGOs are to Retain Trust, (Electronic), www.proquest.umi.com [Accessed: 31 March 2008].

Moldoveanu Michnea et al (2001), Agency theory and the design of an efficient governance mechanism, Rotman school of management, University of Toronoto.

Najam, A. (1996), NGO Accountability: A Conceptual Framework, Development Policy Review, Vol. 14, pp. 339-53.

National Audit Office (2001), Joining up to Improve Public Services, Available at: www.nao.gov. uk/publications/nao_reports/index.htm (accessed 18 May 2008).

National Audit Office (2001), Measuring the Performance of Government Department available at: www.nao.gov.uk/publications/nao_reports/index.htm (access 14 May 2008).

Neligan, C., (2003), Accountability Matters for INGOs, BOND.NGO Watch, (2004), NGO Watch - İnformation , (Electronic), www.ngowatch.org/info.htm [Accessed; 31 March 2008].

O’Donovan, G. R. (2002). Accountability, Impression Management, and Goal Setting in the Performance Evaluation Process. Human Relations, Vol. 51, 1259 -1283.

Ouchi, W. (1979). A Conceptional Framework for the Design of Organization Control Mechanism. Management Science, Vol. 25 No. 4, pp. 833-848.

Patten, J.E. (2002), Groups: Interaction and Performance. Englewood Cliffs, NJ: Prentice -Hall.

Pomeranz Felix (1997), Auditing Committees; where do we from here, Managerial Auditing Journal Vol. 12 no 6 pp $291-294$.

Power Michael (2002); the audit society Oxford University press.

PriceWaterCoopers (1999), Audit Committees: Good Practices for meeting market expectations PriceWaterCooper, 7 -9 .

Protiviti (2003), The Expanded Responsibilities of the Audit Committees, A New Mandare, Bulletin Vol. 1 İssue 9.

Reinstein Allan et al (1996), Testing for bias in the audit committee, Managerial Auditing Journal Vol. 11 no 2 pp 28 -35 .

Roberts, M. R. (2002), Surprise and Sense-Making; What newcomers experience when entering unfamiliar organizational settings. Administrative Science Quarterly vol. 25, 226-251. 
Ross, S. and Mitnick, B., (1973), The Economic Theory of Agency. American Economic Review Proceedings, May.

Schlenker, B. R., Britt, T. W., Pennington, J., Murphy, r., \& Doherty, K. (2004). The Triangle Model of Responsibility. Psychological Review, 101, 632-652.

Shamira Hussein (2003), The effect of audit committees on major disclosures and other non-financial characteristics of companies listed at the NSE. Unpublished University of Nairobi.

Slim, H., (2002), By What Authority? The Legitimacy and Accountability of Non-Governmental Organizations, The Journal of Humanitarian Assistance, (Electronic), www.jha.ac/articles/a082.htm [Accessed: 31 March 2008].

Stewart, J.D., (1984), The Role of Information in Public Accountability, İn Hopwood, A.G. and Tomkins, C.R. (Eds), İssues in Public Sector Accounting, Oxford, Philip Allen.

Tackett James et al (2004), Sarbanes - Oxley and audit failure management auditing Journal vol. 19 no 3 ppc 340 35.

Terrell Mark (2003), Avalanche of corporate governance reforms challenges audit on effective oversight , Directorship.

Terrell Mark et al (2002), CFOs and audit committees: mutual expectations' Financial executive.

Tomaszewski, L., and McCarthey, L.B., (2005), Accountability of Nonprofit Organizations and those Who Control them; The Legal Framework, Nonprofit Management \& Leadership, Vol. 6 No. 2, pp. 141-156.

Treadway Commission, (1987), Report of he National Commission of Fraudulent financial reporting, Washington.

Tricker, S. A., (1983), On the Edge of the Organization- the Role of the Outside Director, Wiley, London.

Ullman, J.J. (1995). The Development of Working Relationships. Englewood Cliffs, NJ, USA: Prentice-Hall.

Uphoff, N., (1996), Why NGOs are Not a Third Sector. A Sectorial Analysis with Some Thoughts on Accountability, Sustainability and Evaluation, in Edwards.

USA Congress (2002), Sarbanes-Oxley Act, $107^{\text {th }}$ edition Washington, DC.

Vinten Gerald (1998); Corporate governance: An İnternational state of the art, Managerial Auditing Journal.

Vinten Gerald (2002); the Corporate governance lessons of Enron, Corporate Governance Vol. 2 no. 4 pp 4 - 9 MCB University Press.

Wapner, P., (2002). Introductory Essay: Paradise Lost? NGOs and Global Accountability, Chicago Journal of İnternational law, Vol. 3 No.1

Welman, J.C., Kruger, S.J. (2001), Research Methodology, $2^{\text {nd }}$ ed., Oxford University, Cape Town.

Wilkins, P. (2002), Accountability and Joined-Up Government, Australian Journal of Public Administration, Vol. 61 No. 1, pp. $114-19$.

Zabihollah Razee (2003); Improving corporate governance: The role of audit committees University of Memphis Management Auditing Journal Vol. 18 no 6/7 530 - 537.

Zakaria İdrian (2003), 'Lemonade stalls, agency theory and corporate governance.

Zaman Mahbub (2001), Generating undue expectations of the corporate governance role of audit committees , Managerial Auditing Journal Vol 10 no 1 pp $5-9$. 


\begin{tabular}{|c|c|}
\hline$A A P$ & Annual Audit Plan \\
\hline$A C$ & Audi committee \\
\hline$C D C$ & Constituency Development Committee \\
\hline$C D F$ & Constituency Development Fund \\
\hline CEO & Chief Executive Officer \\
\hline CFO & Chief Finance Officer \\
\hline$C M A$ & Capital Markets Authority \\
\hline$\dot{I} A S$ & International Accounting Standards \\
\hline$\dot{I} \dot{I} A$ & Institute of Internal Auditors \\
\hline$\dot{I M F}$ & International Monetary Fund \\
\hline$K C C$ & Kenya Cooperative Creameries \\
\hline$K N A C$ & Kenya National Assurance Company \\
\hline$L A T F$ & Local Authority Transfer Fund \\
\hline$M O U$ & Memorandum of Understanding \\
\hline$M P$ & Member of Parliament \\
\hline$M S C$ & Mumias Sugar Company \\
\hline$N A R C$ & National Alliance Rainbow Coalition \\
\hline$N S E$ & Nairobi Stock Exchange \\
\hline$N T A$ & National Tax Payers Association \\
\hline$S C A C$ & State Corporations Advisory Committee \\
\hline$S P S S$ & Statistical Package for Social Sciences \\
\hline$U K$ & United Kingdom \\
\hline$U S A$ & United States of America \\
\hline$W B$ & World Bank \\
\hline
\end{tabular}

